\title{
A Systematic Review of Mechanical Lumbar Disc Decompression with Nucleoplasty
}

Laxmaiah Manchikanti, MD1, Richard Derby, $\mathrm{MD}^{2}$, Ramsin M. Benyamin, MD², Standiford Helm, MD ${ }^{4}$, and Joshua A. Hirsch, MD ${ }^{5}$

From: ${ }^{1}$ Pain Management Center of Paducah, Paducah, KY; ${ }^{2}$ Spinal

Diagnostics \& Treatment Center, Daly City, CA; ${ }^{3}$ Millennium Pain Center, Bloomington, IL; ${ }^{\text {Pacific }}$ Coast Pain Management Center, Laguna Hills, CA; and Massachusetts General Hospital and Harvard Medical School, Boston, MA

Dr. Manchikanti is Medical Director of the Pain Management Center of Paducah, Paducah, KY. Dr. Derby is Medical Director of Spinal Diagnostics \& Treatment Center, Daly City, CA, and Associate Professor, Department of Physical

Medicine and Rehabilitation, Stanford University, Stanford,

CA. Dr. Benyamin is the Medical Director, Millennium Pain Center, Bloomington, IL, Clinical Assistant Professor of Surgery, College of Medicine, University of Illinois, Urbana-Champaign, IL. Dr. Helm is Medical Director, Pacific Coast Pain Management Center, Laguna Hills, CA. Dr. Hirsch is Chief of Minimally Invasive Spine Surgery, Depts. of Radiology and Neurosurgery, Massachusetts General Hospital and Assistant Professor of Radiology, Harvard Medical School Boston, MA.

Address correspondence: Laxmaiah Manchikanti, MD 2831 Lone Oak Road

Paducah, Kentucky 42003 E-mail:drlm@thepainmd.com

Disclaimer: There was no external funding in the preparation of this manuscript.

Conflict of interest: Dr. Hirsch previously served as a consultant for Arthrocare.

Manuscript received: 03/10/2009 Accepted for publication: 04/29/2009

Free full manuscript: www.painphysicianjournal.com
Background: Lumbar disc prolapse, protrusion, or extrusion account for less than $5 \%$ of all low back problems, but are the most common causes of nerve root pain and surgical interventions. The primary rationale for any form of surgery for disc prolapse is to relieve nerve root irritation or compression due to herniated disc material. The primary modality of treatment continues to be either open or microdiscectomy, but several alternative techniques including nucleoplasty, automated percutaneous discectomy, and laser discectomy have been described. There is a paucity of evidence for all decompression techniques, specifically alternative techniques including nucleoplasty.

Study Design: A systematic review of the literature.

Objective: To determine the effectiveness of mechanical lumbar disc decompression with nucleoplasty.

Methods: A comprehensive evaluation of the literature relating to mechanical lumbar disc decompression with nucleoplasty was performed. The literature was evaluated according to Cochrane review criteria for randomized controlled trials (RCTs), and Agency for Healthcare Research and Quality (AHRQ) criteria was utilized for observational studies.

The level of evidence was classified as Level I, II, or III with 3 subcategories in Level II based on the quality of evidence developed by the United States Preventive Services Task Force (USPSTF).

A literature search was conducted using only English language literature through PubMed, EMBASE, the Cochrane library, systematic reviews, and cross-references from reviews and systematic reviews.

Outcome Measures: Pain relief was the primary outcome measure. Other outcome measures were functional improvement, improvement of psychological status, opioid intake, and return to work.

Short-term effectiveness was defined as one year or less, whereas, long-term effectiveness was defined as greater than one year.

Results: Based on USPSTF criteria the level of evidence for nucleoplasty is Level II-3 in managing predominantly lower extremity pain due to contained disc herniation.

Limitations: Paucity of literature, both observational and randomized.

Conclusion: This systematic review illustrates Level II-3 evidence for mechanical lumbar percutaneous disc decompression with nucleoplasty in treatment of leg pain. However, there is no evidence available in managing axial low back pain.

Key words: Intervertebral disc disease, chronic low back pain, disc herniation, disc protrusion, radiculitis, contained disc herniation, mechanical disc decompression, nucleoplasty, coblation technology, nucleotomy

Pain Physician 2009; 12:561-572 
$\mathrm{n}$ recent years, there has been a gradual shift towards less invasive treatments for disc herniation, including chymopapain, automated percutaneous disc decompression, laser disc decompression, and more recently, minimally invasive nuclear decompression using a bipolar radiofrequency device - also known as nucleoplasty (1). Lumbar disc prolapse, protrusion, or herniation account for less than $5 \%$ of all low back problems, but are the most common causes of nerve root pain. Chemonucleolysis, percutaneous nucleotomy, percutaneous discectomy, and laser treatments incorporate different approaches to percutaneous disc decompression, and all have been shown to reduce intradiscal pressure (2-7). However, each treatment has its limitations and success rates vary considerably (8-17).

Absolute indications for surgery include altered bladder function and progressive muscle weakness, but these are rare (15). The usual indication for surgery is to provide more rapid relief of pain and disability in the minority of patients whose recovery is unacceptably low (15). The primary goal of surgical treatment of nerve root compression is the relief of compression by removing the herniated nuclear material. Historically, the primary modality of treatment has been open discectomy. However, disc herniations consists of both contained and non-contained types. While for non-contained disc herniations, open discectomy is the approach of choice (15), partial removal of the nucleus pulposus in contained discs has been shown to decompress herniated discs and relieve pressure on nerve roots in a much less invasive manner (12-20).

Nucleoplasty, a minimally invasive procedure, uses radiofrequency energy to remove nucleur material and create small channels within the disc (2). With Coblation technology, radiofrequency energy is applied to a conductive medium, creating a highly focused plasma field to form around the energized electrodes (2). The plasma field is composed of highly ionized particles (2). The created channel is thermally treated, producing a zone of thermal coagulation. Thus, nucleoplasty combines coagulation and tissue ablation (patented Coblation technology) to form channels in the nucleus and decompress the herniated disc. Claims have been made over the past few years that nucleoplasty can produce satisfactory results with fewer serious complications. However, these claims not only remain controversial, but also utilization of intradiscal therapies and percutaneous mechanical disc decompression continue to increase (21-26).

Gibson and Waddell (15) in the Cochrane Collaboration review presented the results from 40 randomized controlled trials (RCTs) and 2 quasi-randomized controlled trials (QRCTs) of surgical interventions for lumbar disc prolapse including 17 new trials since the first issue of the review. This review indicated that the place for alternative forms of discectomy other than traditional open discectomy is unresolved. They noted that as of January 2007 there were no RCTs examining coblation as a treatment for disc prolapse.

Gibson and Waddell (15) concluded that there is considerable evidence that surgical discectomy provides effective clinical relief for carefully selected patients with sciatica due to lumbar disc prolapse that fails to resolve with conservative management. They noted that the choice of micro- or standard discectomy at present probably depends more on the training and expertise of the surgeon and the resources available than on scientific evidence of efficacy. In addition, they concluded that, at present, unless or until better scientific evidence is available, multiple minimally invasive decompression techniques including coblation therapy should be regarded as research techniques.

Mixter and Barr (27) reported on the open surgical treatment for rupture of the intervertebral disc in 1934. Less radical procedures started to appear as early as 1939 (28). In 1959, Smith (29) coined the term chemonucleolysis to describe the enzymatic dissolution of the nucleus pulposus as an alternative less invasive means of decompressing the bulging or herniated disc. Hijikata (30) described manual percutaneous lumbar discectomy in the 1970s. In 1985, Onik et al (31) described automated percutaneous lumbar discectomy, a minimally invasive method with aspiration of nucleus for treating contained disc herniations. More recently plasma nucleoplasty utilizing Coblation technology $(1,2,32)$ has been described.

The Centers for Medicare and Medicaid Services (CMS) (33) has recently issued a non-certification for intradiscal procedures. CMS (33) refers to multiple procedures collectively as thermal intradiscal procedures, including percutaneous or (plasma) disc decompression (PDD), or coblation along with other intradiscal therapies.

This systematic review is undertaken to evaluate the current evidence supporting the use of percutaneous mechanical disc decompression with nucleoplasty to treat symptomatic disc protrusions. 


\section{Methods}

\section{Literature Search}

Databases reviewed were PubMed, EMBASE, the Cochrane Library, and the Database of Reviews of Effectiveness (DARE). Bibliographies of reviewed papers were also examined. In addition, authors known to be active in the field were contacted. The time frame covered was 1966 to January 2009.

Inclusion criteria were:

1. Lumbar disc related pain of at least 3 months duration,

2. The mechanical disc decompression with nucleoplasty.

3. Minimum of 12-month follow-up.

4. At least 50 patients included in observational studies.

Search terms included intervertebral disc, degenerative disc disease, disc herniation, disc protrusion, disc extrusion, disc prolapse, disc displacement, radiculitis, nucleoplasty, microdiscectomy, mechanical disc decompression, coblation, and nuclear decompression.

Only articles in English or with English abstracts, systematic reviews, RCTs, and observational studies were reviewed. Discrepancies in rating were resolved by adjudication by a third reviewer. If there was a conflict of interest with the reviewed manuscripts such as authorship or any other type of conflict, the involved authors did not review the manuscripts for quality assessment, clinical relevance, evidence synthesis, or grading of evidence.

\section{Methodologic Quality Assessment}

The method of quality assessment was a function of the type of study. For RCTs, the Cochrane review criteria were used (34). Assessment of study quality for observational studies was done according to the Agency for Healthcare Research and Quality (AHRQ) criteria (35). Both the RCTs and observational forms provide a maximum of 100 points; only studies with scores of over 50 points were included. Consensus-based weighted scoring developed by the guidelines committee of the American Society of Interventional Pain Physicians (ASIPP) was utilized. The same scoring system has been used in multiple evaluations (12-14,36-49).

\section{Outcome Measures}

Pain relief was the primary outcome measure. Other outcome measures were functional improvement, improvement of psychological status, and return to work.

A decrease of either 2 points or $30 \%$ of pain scores provides a useful benchmark of clinical importance to assess effectiveness $(50,51)$. Similarly, a $10 \%$ improvement in functioning outcomes provides an accepted benchmark of clinically useful benefit (52). However, in interventional pain management settings, a significant improvement has been defined as $50 \%$ or more relief, whereas significant improvement in disability has been defined as a $40 \%$ or more decrease in disability scores in multiple publications (53-62).

Significant pain relief $(\geq 50 \%)$ of short-term $(\leq 12$ months) and long-term (> 12 months) was the primary outcome measure. Secondary outcomes included functional or psychological improvement, improvement in work status, and complications.

The inclusion of observational studies, in addition to RCTs, improves the generalizability of conclusions regarding the application of percutaneous mechanical disc decompression with nucleoplasty $(53-55,63,64)$.

\section{Analysis of Evidence}

Level of evidence was determined based on the United States Preventive Services Task Force (USPSTF) criteria using 5 levels of evidence, ranging from Level I to III with 3 subcategories in Level II, as illustrated in Table 1 (65).

Table 1. Quality of evidence developed by USPSTF.

\begin{tabular}{|c|l|}
\hline \hline I: & Evidence obtained from at least one properly randomized controlled trial \\
\hline II-1: & Evidence obtained from well-designed controlled trials without randomization \\
\hline II-2: & $\begin{array}{l}\text { Evidence obtained from well-designed cohort or case-control analytic studies, preferably from more than one center or research } \\
\text { group }\end{array}$ \\
\hline II-3: & $\begin{array}{l}\text { Evidence obtained from multiple time series with or without the intervention. Dramatic results in uncontrolled experiments (such } \\
\text { as the results of the introduction of penicillin treatment in the 1940s) could also be regarded as this type of evidence }\end{array}$ \\
\hline III: & Opinions of respected authorities, based on clinical experience descriptive studies and case reports or reports of expert committees \\
\hline
\end{tabular}

Adapted from the U.S. Preventive Services Task Force (USPSTF) (65). 


\section{Recommendations}

Recommendations for effectiveness were made according to Guyatt et al's criteria (66) (Table 2).

\section{Results}

The results of literature search for mechanical disc decompression procedures with nucleoplasty are illustrated in Fig. 1. A total of 16 articles $(2,67-81)$ were located in the literature search. There were no RCTs identified.

\section{Methodological Quality Assessment}

There were no RCTs identified evaluating nucleoplasty. However, 16 observational studies were identified describing mechanical disc decompression with nucleoplasty $(2,67-81)$. Eleven studies were excluded for the various reasons described in Table 3. Overall 5 observational studies met the inclusion criteria for methodologic quality assessment $(67,71,72,77,80)$.
Table 3. Reasons for exclusion of observational studies of nucleoplasty.

\begin{tabular}{|l|l||}
\hline \multicolumn{1}{|c|}{ Study } & \multicolumn{1}{c|}{ Reason for Exclusion } \\
\hline Cohen et al (76) & $<50$ patients (9 patients) \\
\hline Bhagia et al (75) & Descriptions of side effects \\
\hline Chen et al (32) & Experimental study \\
\hline Wang et al (79) & Experimental study \\
\hline Chen et al (2) & Experimental study \\
\hline Welch \& Gerszten (69) & $\begin{array}{l}\text { Review of procedures with description of } \\
25 \text { patients }\end{array}$ \\
\hline Singh et al (70) & $<50$ patients (47 patients) \\
\hline Sharps \& Isaac (68) & $\begin{array}{l}<50 \text { patients (49 patients), majority short- } \\
\text { term follow-up }\end{array}$ \\
\hline Gerszten et al (73) & Short-term follow-up \\
\hline Reddy et al (78) & $<50$ patients (49 patients) \\
\hline Yakovlev et al (81) & $<50$ patients (22 patients) \\
\hline \hline
\end{tabular}

Table 2. Grading recommendations.

\begin{tabular}{|c|c|c|c|}
\hline $\begin{array}{l}\text { Grade of Recommendation/ } \\
\text { Description }\end{array}$ & $\begin{array}{l}\text { Benefit vs Risk and } \\
\text { Burdens }\end{array}$ & $\begin{array}{l}\text { Methodological Quality of } \\
\text { Supporting Evidence }\end{array}$ & Implications \\
\hline $\begin{array}{l}\text { 1A/strong recommendation, } \\
\text { high-quality evidence }\end{array}$ & $\begin{array}{l}\text { Benefits clearly out- } \\
\text { weigh risk and burdens, } \\
\text { or vice versa }\end{array}$ & $\begin{array}{l}\text { RCTs without important limitations or } \\
\text { overwhelming evidence from observa- } \\
\text { tional studies }\end{array}$ & $\begin{array}{l}\text { Strong recommendation, can apply } \\
\text { to most patients in most circum- } \\
\text { stances without reservation }\end{array}$ \\
\hline $\begin{array}{l}\text { 1B/strong recommendation, } \\
\text { moderate quality evidence }\end{array}$ & $\begin{array}{l}\text { Benefits clearly out- } \\
\text { weigh risk and burdens, } \\
\text { or vice versa }\end{array}$ & $\begin{array}{l}\text { RCTs with important limitations (incon- } \\
\text { sistent results, methodological flaws, indi- } \\
\text { rect, or imprecise) or exceptionally strong } \\
\text { evidence from observational studies }\end{array}$ & $\begin{array}{l}\text { Strong recommendation, can apply } \\
\text { to most patients in most circum- } \\
\text { stances without reservation }\end{array}$ \\
\hline $\begin{array}{l}\text { 1C/strong recommendation, } \\
\text { low-quality or very low-quality } \\
\text { evidence }\end{array}$ & $\begin{array}{l}\text { Benefits clearly out- } \\
\text { weigh risk and burdens, } \\
\text { or vice versa }\end{array}$ & Observational studies or case series & $\begin{array}{l}\text { Strong recommendation but may } \\
\text { change when higher quality evidence } \\
\text { becomes available }\end{array}$ \\
\hline $\begin{array}{l}\text { 2A/weak recommendation, high- } \\
\text { quality evidence }\end{array}$ & $\begin{array}{l}\text { Benefits closely bal- } \\
\text { anced with risks and } \\
\text { burden }\end{array}$ & $\begin{array}{l}\text { RCTs without important limitations or } \\
\text { overwhelming evidence from observa- } \\
\text { tional studies }\end{array}$ & $\begin{array}{l}\text { Weak recommendation, best action } \\
\text { may differ depending on circum- } \\
\text { stances or patients' or societal values }\end{array}$ \\
\hline $\begin{array}{l}\text { 2B/weak recommendation, mod- } \\
\text { erate-quality evidence }\end{array}$ & $\begin{array}{l}\text { Benefits closely bal- } \\
\text { anced with risks and } \\
\text { burden }\end{array}$ & $\begin{array}{l}\text { RCTs with important limitations (incon- } \\
\text { sistent results, methodological flaws, indi- } \\
\text { rect, or imprecise) or exceptionally strong } \\
\text { evidence from observational studies }\end{array}$ & $\begin{array}{l}\text { Weak recommendation, best action } \\
\text { may differ depending on circum- } \\
\text { stances or patients' or societal values }\end{array}$ \\
\hline $\begin{array}{l}\text { 2C/weak recommendation, } \\
\text { low-quality or very low-quality } \\
\text { evidence }\end{array}$ & $\begin{array}{l}\text { Uncertainty in the esti- } \\
\text { mates of benefits, risks, } \\
\text { and burden; benefits, } \\
\text { risk, and burden may } \\
\text { be closely balanced }\end{array}$ & Observational studies or case series & $\begin{array}{l}\text { Very weak recommendations; } \\
\text { other alternatives may be equally } \\
\text { reasonable }\end{array}$ \\
\hline
\end{tabular}

Adapted from Guyatt $\mathrm{G}$ et al. Grading strength of recommendations and quality of evidence in clinical guidelines. Report from an American College of Chest Physicians task force. Chest 2006; 129:174-181 (66). 


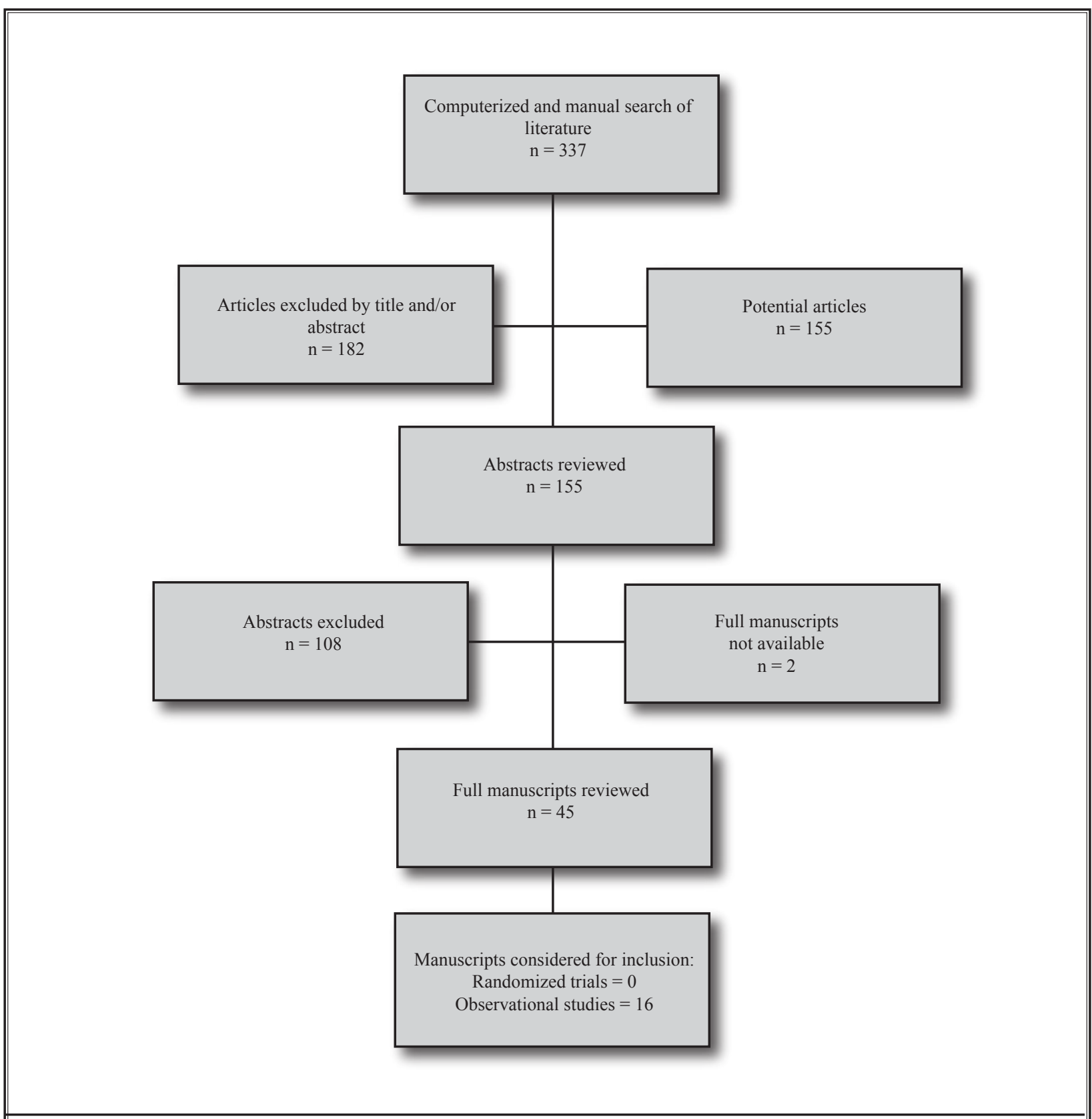

Fig. 1. The flow diagram illustrating studies evaluating mechanical disc decompression with nucleoplasty.

Methodologic quality scores are described in Table 4, ranging from 51 to 77 . Of these, all studies scored 50 or above and met the methodologic quality assessment criteria for evidence synthesis.

\section{Study Characteristics}

Gibson and Waddell (15) in the systematic review of surgical interventions for lumbar disc prolapse of randomized trials concluded that there were no RCTs 
Pain Physician: May/June 2009: 12:561-572

Table 4. Methodological assessment of observational studies evaluating the effectiveness of nucleoplasty

\begin{tabular}{|c|c|c|c|c|c|c|}
\hline CRITERION & $\begin{array}{c}\text { Weighted } \\
\text { Score } \\
\text { (points) }\end{array}$ & $\begin{array}{l}\text { Mirzai et } \\
\text { al (77) }\end{array}$ & $\begin{array}{l}\text { Singh et al } \\
\quad(67)\end{array}$ & $\begin{array}{l}\text { Singh et al } \\
\quad(71)\end{array}$ & Marin (72) & $\begin{array}{c}\text { Al-Zain et } \\
\text { al (80) }\end{array}$ \\
\hline 1. Study Question & 2 & 2 & 2 & 2 & 2 & 2 \\
\hline \multicolumn{7}{|l|}{ - Clearly focused and appropriate question } \\
\hline 2. Study Population & 8 & 5 & 5 & 5 & 5 & 5 \\
\hline - Description of study population & 5 & 5 & 5 & 5 & 5 & 5 \\
\hline - Sample size justification & 3 & - & - & - & - & - \\
\hline 3. Comparability of Subjects & 22 & 11 & 11 & 11 & 11 & 14 \\
\hline - Specific inclusion/exclusion criteria for all groups & 5 & 5 & 5 & 5 & 5 & 5 \\
\hline - Criteria applied equally to all groups & 3 & 3 & 3 & 3 & 3 & 3 \\
\hline $\begin{array}{l}\text { - Comparability of groups at baseline with regard to } \\
\text { disease status and prognostic factors }\end{array}$ & 3 & - & - & - & - & - \\
\hline $\begin{array}{l}\text { - Study groups comparable to non-participants with } \\
\text { regard to confounding factors }\end{array}$ & 3 & - & - & - & - & 3 \\
\hline - Use of concurrent controls & 5 & - & - & - & - & - \\
\hline $\begin{array}{l}\text { - Comparability of follow-up among groups at each } \\
\text { assessment }\end{array}$ & 3 & 3 & 3 & 3 & 3 & 3 \\
\hline 4. Exposure or Intervention & 11 & 8 & 7 & 7 & 10 & 10 \\
\hline - Clear definition of exposure & 5 & 5 & 5 & 5 & 5 & 5 \\
\hline - Measurement method standard, valid and reliable & 3 & 3 & 2 & 2 & 3 & 3 \\
\hline - Exposure measured equally in all study groups & 3 & - & - & - & 2 & 2 \\
\hline 5. Outcome measures & 20 & 18 & 11 & 11 & 8 & 13 \\
\hline - Primary/secondary outcomes clearly defined & 5 & 5 & 3 & 3 & 3 & 5 \\
\hline - Outcomes assessed blind to exposure or intervention & 5 & 3 & - & - & - & - \\
\hline $\begin{array}{l}\text { - Method of outcome assessment standard, valid and } \\
\text { reliable }\end{array}$ & 5 & 5 & 3 & 3 & 2 & 3 \\
\hline - Length of follow-up adequate for question & 5 & 5 & 5 & 5 & 3 & 5 \\
\hline 6. Statistical Analysis & 19 & 15 & 10 & 10 & - & 13 \\
\hline - Statistical tests appropriate & 5 & 5 & 5 & 5 & - & 5 \\
\hline - Multiple comparisons taken into consideration & 3 & 3 & 3 & 3 & - & 3 \\
\hline - Modeling and multivariate techniques appropriate & 2 & 2 & 2 & 2 & - & - \\
\hline - Power calculation provided & 2 & - & - & - & - & - \\
\hline - Assessment of confounding & 5 & 5 & - & - & - & 5 \\
\hline - Dose-response assessment if appropriate & 2 & - & - & - & - & - \\
\hline 7. Results & 8 & 8 & 6 & 6 & 5 & 7 \\
\hline $\begin{array}{l}\text { - Measure of effect for outcomes and appropriate } \\
\text { measure of precision }\end{array}$ & 5 & 5 & 3 & 3 & 3 & 5 \\
\hline - Adequacy of follow-up for each study group & 3 & 3 & 3 & 3 & 2 & 2 \\
\hline 8. Discussion & 5 & 5 & 5 & 5 & 5 & 5 \\
\hline $\begin{array}{l}\text { - Conclusions supported by results with possible biases } \\
\text { and limitations taken into consideration }\end{array}$ & 5 & 5 & 5 & 5 & 5 & 5 \\
\hline 9. Funding or Sponsorship & 5 & 5 & 5 & 5 & 5 & 5 \\
\hline - Type and sources of support for study & 5 & 5 & 5 & 5 & 5 & 5 \\
\hline TOTAL SCORE= & 100 & 77 & 62 & 62 & 51 & 74 \\
\hline
\end{tabular}

Adapted and modified from West S et al. Systems to Rate the Strength of Scientific Evidence, Evidence Report, Technology Assessment No. 47. AHRQ Publication No. 02-E016 (35). 
examining coblation as a treatment for disc prolapse. Similarly, no randomized trials have been identified for this review. However, nucleoplasty has been studied in multiple observational studies $(2,67-81)$ and of these 5 studies $(67,71,72,77,80)$ met inclusion criteria.

Mirzai et al (77) published the results of nucleoplasty in 52 consecutive patients with lumbar herniated discs. Mean VAS reduced from pre-procedure 7.5 to 3.1 at post procedure 6 months and 2.1 at the latest follow-up, with a mean follow-up of $12.1 \pm 1.6$ months. Similarly, mean Oswestry Index decreased from 42.2 to 24.8 at 6 months and 20.5 at the latest examination. Analgesic consumption was stopped or reduced in 42 patients $(85 \%)$ at 6 months and 46 patients $(94 \%)$ one-year after the procedure, with an overall patient satisfaction of $85 \%$ at 6 months and $88 \%$ at the latest follow-up.

Among the 52 patients in the series, 34 had one disc treated and 18 had 2 discs treated. All procedures were considered technically successful, with the full treatment protocol carried out to completion. There were no complications associated with the procedure during follow-up periods. Among the successful patients, complete resolution of symptoms was seen in $77 \%$ of the patients at 6 months, and in $84 \%$ at the latest follow-up. Eight patients did not have any clinical resolution at 6 months, and 4 had no resolution at the latest follow-up. Two patients had to be operated on 7 and 10 days after nucleoplasty because of severe pain continuing despite clinically successful procedures. The authors felt that favorable results were probably due to strict patient selection criteria, including radicular pain greater than back pain, failure of previous medical treatment and physiotherapy, MRI evidence of small and medium-sized contained disc herniations (less than $6 \mathrm{~mm}$ ). Further exclusion criteria included spondylolisthesis, segmental instability, and a large ( $\geq 6 \mathrm{~mm}$ ) or extruded disc herniation. They also did not perform the procedures in patients older than 60 years, disc height less than $50 \%$ compared with the adjacent disc segment, and back pain greater than leg pain. Discography was routinely performed prior to nucleoplasty. They postulated that discography is important to diagnose the integrity of the outer annulus. They stated that if the outer annulus is compromised, it is unlikely that the patient will benefit from this procedure. However, they did not include positive concordant discography as inclusion criteria. Thus, discography was performed to evalu- ate the annular integrity, not to determine whether concordant pain was produced.

Among 3 studies published by Singh et al $(67,70,71), 2$ studies $(67,71)$ met inclusion criteria. Singh et al (67) reported results on a group of 67 patients with chronic low back pain and leg pain of long duration. Outcomes were available in 61 patients at 6 months and 41 patients at 12 months. The average decrease in numeric pain score was $38 \%$, from a preoperative average 6.8 , numerical pain rating score decreased $>50 \%$ and $59 \%$ at 6 months and $56 \%$ at 12 months. The authors reported improvement in self-reported sitting and standing tolerance. They also studied a consecutive series of 84 low back pain patients with or without leg pain (71). They reported a $34 \%$ decrease in the numerical pain rating score at 12 months. Fifteen percent of the patients unemployed before nucleoplasty returned to work after the study intervention. The authors concluded that this analysis demonstrated an encouraging outcome following nucleoplasty. Functional improvement was observed in $62 \%, 59 \%$, and $60 \%$ of the patients for sitting, standing, and walking abilities, respectively. They also showed a significant correlation between pain relief and functional improvement. Overall, $75 \%$ of patients indicated a decrease in their numeric pain scores at 12 months with a statistically significant reduction in numeric pain scores compared to baseline. A total of $54 \%$ of patients indicated pain relief of $50 \%$ or more at 12 months. Additionally, significant improvement was reported by $54 \%, 44 \%$, and $49 \%$ of patients in sitting, standing, and walking abilities, respectively, at 12 months. There were no complications noted. The authors concluded that nucleoplasty is a safe and efficacious procedure for reducing discogenic low back pain with or without leg pain.

Al-Zain et al (80) evaluated 69 patients undergoing nucleoplasty with one-year follow-up. The mean age of the 27 females (39\%) and 42 males in this study was 42 years, age ranging from 18 to 74 . The mean duration of symptoms was 30.5 months. Forty-two percent of patients were smokers and the mean body mass index was 26.3 . The results showed $73 \%$ of treated patients experiencing an improvement of more than $50 \%$ in their symptoms in the early post-operative period. This was reduced to $61 \%$ at 6 months and $58 \%$ after one-year. A statistically significant reduction in analgesic consumptions, disability, and occupational incapacitation resulted from treatment with nucleoplasty. They concluded that nucleoplasty is an effec- 
tive therapy for chronic, discogenic back pain which results in significant reductions in levels of disability and incapacity for work as well as decreased analgesic consumption.

Marin (72) analyzed 64 patients with contained disc herniation classified into those who underwent percutaneous disc decompression using coblation technology and patients who underwent coblationassisted microdiscectomy (CAM). All patients who presented with percutaneous disc decompression were considered candidates for open surgery, but all of them opted for the new technique. There were no contraindications. They had discogenic low back and/ or leg pain and the procedure was performed on an outpatient basis. Follow-up data was of 1-2 months. Patients' gender distribution for percutaneous disc decompression was $65 \%$ (41.6) male, and 35\% (22.4) female with a mean age of 43 years. The average duration of pain before nucleoplasty was of 18 months and none of them had previous lumbar surgery. At 6 to 12 months, $80 \%$ of the patients demonstrated an improvement in pain scores with $75 \%$ reporting very good response while $5 \%$ reported a good response. None of the patients were worse. Results indicated that nucleoplasty may be an efficacious minimally invasive technique for the treatment of symptoms associated with contained herniated disc.

All these studies showed improvement, however these are all observational. None of them are randomized.

\section{Complications and Side Effects}

Bhagia et al (75) evaluated side effects and com- plications after percutaneous disc decompression with coblation technology in 53 patients; however, 4 patients dropped out, 2 patients had increased symptoms and opted for surgery, and 2 patients could not be contacted. The most common side effects at 24 hours post-procedure were soreness at the needle insertion site $76 \%$, new numbness and tingling $26 \%$, increased intensity of pre-procedure back pain $15 \%$, and new areas of back pain $15 \%$. At 2 weeks, no patient had soreness at the needle insertion site or new areas of back pain; however, new numbness and tingling was present in $15 \%$ of the patients. Two patients or $4 \%$ had increased intensity of pre-procedure back pain. Chen et al (32) in an experimental nucleoplasty study of histologic findings of disc, end plate, and neural elements after coblation of nucleus pulposus suggested that the nucleoplasty achieves volumetric removal of target disc tissue without overt thermal or structural damage to the adjacent tissues. Histologic examination revealed no evidence of direct mechanical or thermal damage of the surround tissues. There was clear evidence of coblation channels with clean coagulation borders of the nucleus pulposus. They also found normal histologic findings of the annulus and end plate, with normal neural elements of the spinal cord and nerve roots at the level of the procedure.

\section{Level of Evidence}

Based on USPSTF criteria (65), the indicated evidence for nucleoplasty is Level II-3 (Table 5) in managing predominantly lower extremity pain due to contained disc herniation. There is no evidence available for axial low back pain.

Table 5. Results of published evaluations of nucleoplasty.

\begin{tabular}{|c|c|c|c|c|c|c|c|}
\hline \multirow[b]{2}{*}{ Study } & \multirow{2}{*}{$\begin{array}{c}\text { Study } \\
\text { Characteristics }\end{array}$} & \multirow{2}{*}{$\begin{array}{l}\text { Methodological } \\
\text { Quality Score }\end{array}$} & \multirow{2}{*}{$\begin{array}{c}\text { No. of } \\
\text { patients }\end{array}$} & \multicolumn{2}{|c|}{ Pain Relief } & \multicolumn{2}{|c|}{ Results } \\
\hline & & & & $6 \mathrm{mos}$ & 1 year & $\begin{array}{c}\text { Short-term } \\
\text { relief } \leq 12 \mathrm{mos}\end{array}$ & $\begin{array}{c}\text { Long-term } \\
\text { relief }>12 \mathrm{mos}\end{array}$ \\
\hline Singh et al (67) & $\mathrm{O}$ & 62 & 67 & $59 \%$ & $56 \%$ & $\mathrm{P}$ & $\mathrm{P}$ \\
\hline Singh et al (71) & $\mathrm{O}$ & 62 & 80 & $76 \%$ & $77 \%$ & $\mathrm{P}$ & $\mathrm{P}$ \\
\hline Marin (72) & $\mathrm{O}$ & 61 & 64 & $80 \%$ & $80 \%$ & $\mathrm{P}$ & $\mathrm{P}$ \\
\hline Mirzai et al (77) & $\mathrm{O}$ & 77 & 52 & $85 \%$ & $88 \%$ & $\mathrm{P}$ & $\mathrm{P}$ \\
\hline Al-Zain et al (80) & $\mathrm{O}$ & 74 & 69 & $61 \%$ & $58 \%$ & $\mathrm{P}$ & $\mathrm{P}$ \\
\hline
\end{tabular}

$\mathrm{O}=$ Observational $; \mathrm{P}=$ positive 


\section{Recommendations}

The recommendation based on Guyatt et al's (66) criteria is $2 \mathrm{~B} /$ weak recommendation in managing radicular pain due to contained disc herniation. No recommendation is available in managing axial low back pain.

\section{Discussion}

This systematic review evaluated the role of lumbar disc decompression with nucleoplasty. The present evidence for nucleoplasty is Level II-3 with 2B/weak recommendation in managing radicular pain due to contained disc herniation.

Nucleoplasty utilizing Coblation technology dissolves the nuclear material through molecular dissociation, and is thought to lower nuclear pressure, thereby reducing the nerve root tension and allowing a protrusion to implode inward. There is lack of systematic reviews for nucleoplasty. However, Derby et al (1) evaluated the evidence-informed management of chronic low back pain with minimally invasive nuclear decompression and concluded that nucleoplasty does not support the treatment of back pain alone, but the procedure is better suited for the improvement of referred extremity pain in patients with protrusion less than 4 to $6 \mathrm{~mm}$, minimal stenosis, and relatively well-maintained disc heights. Gibson and Waddell (15) in their systematic review concluded that there are no RCTs examining coblation as a treatment for disc prolapse. The present review found multiple observational manuscripts evaluating the effectiveness of nucleoplasty, with 5 of them $(67,71,72,77,80)$ meeting methodologic quality assessment criteria for inclusion. In general, all the studies showed positive results. A total of 332 patients were evaluated in the studies that had at least 50 patients and one-year follow-up and relief ranged from $56 \%$ to $80 \%$ with an average of $71 \%$ of patients on average showing improvement, based on 5 studies.

Derby et al (1) summarized the evidence stating that we have yet to discover the cure for chronic low back pain. Relying on the published literature, they concluded that for the treatment of chronic low back pain caused by a disrupted and mildly protruding disc, there is no treatment that stands head and shoulders above the rest. Nucleoplasty and other minimally invasive nuclear decompression devices are trying to bridge the gap between non-invasive treatment modalities and surgical fusion. The techniques are only a first iteration. They added that the scientific rationale for these procedures is wanting but not hopeless. They postulated that the targeted removal of herniated nucleus behind a protrusion is a more logical strategy for achieving the desired effect of removing the source of inflammation and relieving tension on the adjacent irritated annulus than open discectomy, fusion or disc arthroplasty. Further, they described that future designs will allow better navigation into protrusions and incorporate enhanced methods to safely remove herniated nuclear material.

In spite of variable results, nucleoplasty is appealing because it is simple, relatively safe, and destroys minimal tissue. Disc height should therefore be maintained or collapse more slowly and allow the body time to adapt. In addition, the 17-gauge introducer needle should cause significantly less collateral damage to normal annulus compared with surgical arthroscopic decompression techniques that remove herniations from inside the disc (1). Because surgical decompression outcome for small protrusions is inconsistent and patients often would like fusion or arthroplasty to be the last resort, nuclear decompression using a minimally invasive technique would seem to be a reasonable next option for hydrated discs with relatively well-maintained disc heights (1). Thus, for patients with chronic low back pain and referred leg pain, nucleoplasty may be an option. Derby et al (1) stated that comparing nucleoplasty to fusion surgery, the reported median decreases in pain scores including both leg and back pain after nucleoplasty are 54\% and median improvement in back-specific impairment scores is $42 \%$ after fusion. Further, nucleoplasty is generally safer than fusion. Finally, once an artificial disc or fusion instrumentation is inserted, there is no turning back (1). However, epidural fibrosis may develop with nucleoplasty (82).

At present, the evidence is only for leg pain. Nucleoplasty may be considered prior to open discectomy, however, automated percutaneous lumbar discectomy and laser discectomy have been shown to have better evidence with extensive experience $(12,13)$.

\section{Conclusion}

This systematic review illustrates Level II-3 evidence for nucleoplasty for mechanical lumbar percutaneous disc decompression with leg pain. Nucleoplasty may provide appropriate relief in properly selected patients with contained disc herniation without significant complications and minimal morbidity. No evidence is available for lumbar axial pain. 
The authors wish to thank the editorial board of Pain Physician for review and criticism in improving the manuscript; Sekar Edem for assistance in search of literature; and Tonie M. Hatton and Diane E. Nei- hoff, transcriptionists (Pain Management Center of Paducah), for their assistance in preparation of this manuscript.

\section{References}

1. Derby R, Baker RM, Lee CH. Evidenceinformed management of chronic low back pain with minimally invasive nuclear decompression. Spine / 2008; 8:150-159.

2. Chen YC, Lee SH, Chen D. Intradiscal pressure study of percutaneous disc decompression with nucleoplasty in human cadavers. Spine 2003; 28:661665.

3. Kambin P, Brager MD. Percutaneous posterolateral discectomy. Anatomy and mechanism. Clin Orthop Relat Res 1987; 223:145-154.

4. Kambin P, Schaffer JL. Percutaneous lumbar discectomy. Review of 100 patients and current practice. Clin Orthop Relat Res 1989; 238:24-34.

5. Karasek M, Bogduk N. Twelve-month follow-up of a controlled trial of intradiscal thermal anuloplasty for back pain due to internal disc disruption. Spine 2000; 25:2601-2607.

6. Nerubay J, Caspi I, Levinkopf M, Tadmor A, Bubis JJ. Percutaneous laser nucleolysis of the intervertebral lumbar disc. An experimental study. Clin Orthop Relat Res 1997; 337:42-44.

7. Sasaki M, Takahashi T, Miyahara K, Hirose $T$. Effects of chondroitinase $A B C$ on intradiscal pressure in sheep: An in vivo study. Spine 2001; 26:463-468.

8. Ohnmeiss DD, Guyer RD, Hochschuler SH. Laser disc decompression. The importance of proper patient selection. Spine 1994; 19:2054-2058.

9. Postacchini F. Management of herniation of the lumbar disc. J Bone Joint Surg Br 1999; 81:567-576.

10. Saal JS, Saal JA. Management of chronic discogenic low back pain with a thermal intradiscal catheter. A preliminary report. Spine 2000; 25:382-388.

11. Stolke D, Sollmann WP, Seifert V. Intra- and postoperative complications in lumbar disc surgery. Spine 1989; 14:5659.
12. Hirsch JA, Singh V, Falco FJE, Benyamin RM, Manchikanti L. Automated percutaneous lumbar discectomy for the contained herniated lumbar disc: A systematic assessment of evidence. Pain Physician 2009; 12:601-620.

13. Singh V, Manchikanti L, Benyamin RM, Helm S, Hirsch JA. Percutaneous lumbar laser disc decompression: A systematic review of current evidence. Pain Physician 2009; 12:573-588.

14. Singh V, Benyamin RM, Datta S, Falco FJE, Helm S, Manchikanti L. Systematic review of percutaneous lumbar mechanical disc decompression utilizing Dekompressor. Pain Physician 2009; 12:589-599.

15. Gibson JNA, Waddell G. Surgical interventions for lumbar disc prolapse. Cochrane Database Syst Rev 2009; (1): CDo01350.

16. Percutaneous Discectomy. Washington State Department of Labor and Industries, Office of Medical Director; February $24,2004$.

17. Boswell MV, Trescot AM, Datta S, Schultz DM, Hansen HC, Abdi S, Sehgal N, Shah RV, Singh V, Benyamin RM, Pate VB, Buenaventura RM, Colson JD, Cordner HJ, Epter RS, Jasper JF, Dunbar EE, Atluri SL, Bowman RC, Deer TR, Hansen HC, Staats PS, Smith HS, Burton AW, Kloth DS, Giordano J, Manchikanti L. Interventional techniques: Evidencebased practice guidelines in the management of chronic spinal pain. Pain Physician 2007; 10:7-111.

18. Brown MD. Update on chemonucleolysis. Spine 1996; 21:62S-68S.

19. Mayer HM. Spine update: Percutaneous lumbar disc surgery. Spine 1994; 19:2719-2723.

20. Kloth DS, Singh V, Manchikanti L. Percutaneous mechanical disc decompression. In: Manchikanti L, Singh V (eds). Interventional Techniques in Chronic Spinal Pain. ASIPP Publishing, Paducah, KY 2007; pp 601-622.
21. Manchikanti L. Medicare in interventional pain management: A critical analysis. Pain Physician 2006; 9:171198.

22. Manchikanti L. The growth of interventional pain management in the new millennium: A critical analysis of utilization in the Medicare population. Pain Physician 2004; 7:465-482.

23. Deyo RA, Gray DT, Kreuter W, Mirza S, Martin BI. United States trends in lumbar fusion surgery for degenerative conditions. Spine 2005; 30:1441-1445.

24. Manchikanti L, Boswell MV. Interventional techniques in ambulatory surgical centers: A look at the new payment system. Pain Physician 2007; 10:627650.

25. Manchikanti L, Giordano J. Physician payment 2008 for interventionalists: Current state of health care policy. Pain Physician 2007; 10:607-626.

26. Manchikanti L, Singh V, Pampati V, Smith HS, Hirsch JA. Analysis of growth in interventional techniques in managing chronic pain in Medicare population: A 10-year evaluation from 1997 to 2006. Pain Physician 2009; 12:9-34.

27. Mixter W, Barr J. Rupture of the intervertebral disc with involvement of the spinal canal. N Engl J Med 1934; 211:210215.

28. Love JG. Removal of the protruded intervertebral discs without laminectomy [editorial]. Proc Mayo Clin 1939; 14:1800.

29. Smith L. Enzyme dissolution of the nucleus pulposus in humans. JAMA 1964; 187:137-140.

30. Hijikata S. Percutaneous nuclectomy: A method of percutaneous nuclear extraction. J Toden Hospital 1975; 5:3944.

31. Onik G, Helms C, Ginsburg L, Hoaglund FT, Morris J. Percutaneous lumbar diskectomy using a new aspiration probe. AJNR 1985; 6:290-293. 
32. Chen YC, Lee SH, Saenz Y, Lehman NL. Histologic findings of disc, end plate and neural elements after coblation of nucleus pulposus: An experimental nucleoplasty study. Spine J 2003; 3:466470.

33. Phurrough S, Salive M, O'Connor D, Schafer J. Decision Memo for Thermal Intradiscal Procedures. 2008 [cited September 30, 2008]. www.cms.hhs. gov/mcd/viewdecisionmemo.asp?fro $\mathrm{m} 2=$ viewdecisionmemo.asp\&id $=215$ \&

34. Koes BW, Scholten RJ, Mens JMA, Bouter LM. Efficacy of epidural steroid injections for low-back pain and sciatica: A systematic review of randomized clinical trials. Pain 1995; 63:279-288.

35. West S, King V, Carey TS, Lohr KN, McKoy N, Sutton SF, Lux L. Systems to Rate the Strength of Scientific Evidence, Evidence Report, Technology Assessment No. 47. AHRQ Publication No. 02 E016. Rockville, MD: Agency for Healthcare Research and Quality, 2002. www. thecre.com/pdf/ahrq-system-strength. pdf

36. Manchikanti L, Singh V, Derby R, Schultz DM, Benyamin RM, Prager JP, Hirsch JA. Reassessment of evidence synthesis of occupational medicine practice guidelines for interventional pain management. Pain Physician 2008; 11:393482.

37. Atluri S, Datta S, Falco FJ, Lee M. Systematic review of diagnostic utility and therapeutic effectiveness of thoracic facet joint interventions. Pain Physician 2008; 11:611-629.

38. Conn A, Buenaventura R, Datta S, Abdi S, Diwan S. Systematic review of caudal epidurals injections in the management of chronic low back pain. Pain Physician 2009; 12:109-135.

39. Parr AT, Diwan S, Abdi S. Lumbar interlaminar epidural injections in manag ing chronic low back and lower extremity pain: A systematic review. Pain Physician 2009; 12:163-188.

40. Buenaventura R, Datta S, Abdi S, Smith HS. Systematic review of therapeutic lumbar transforaminal epidural steroid injections. Pain Physician 2009; 12:233-251.

41. Benyamin R, Singh V, Parr AT, Conn A, Diwan S, Abdi S. Systematic review of the effectiveness of cervical epidurals in the management of chronic neck pain. Pain Physician 2009; 12:137-157.

42. Helm S, Hayek SM, Benyamin RM, Manchikanti L. Systematic review of the effectiveness of thermal annular procedures in treating discogenic low back pain. Pain Physician 2009; 12:207-232.

43. Falco FJE, Erhart S, Wargo BW, Bryce DA, Atluri S, Datta S, Hayek SM. Systematic review of diagnostic utility and therapeutic effectiveness of cervical facet joint interventions. Pain Physician 2009; 12:323-344.

44. Datta S, Lee M, Falco FJE, Bryce DA, Hayek SM. Systematic assessment of diagnostic accuracy and therapeutic utility of lumbar facet joint interventions. Pain Physician 2009; 12:437460

45. Epter RS, Helm S, Hayek SM, Benyamin RM, Smith HS, Abdi S. Systematic review of percutaneous adhesiolysis and management of chronic low back pain in post lumbar surgery syndrome. Pain Physician 2009; 12:361-378.

46. Hayek SM, Helm S, Benyamin RM, Singh V, Bryce DA, Smith HS. Effectiveness of spinal endoscopic adhesiolysis in post lumbar surgery syndrome: A systematic review. Pain Physician 2009; 12:419-435.

47. Frey ME, Manchikanti L, Benyamin RM, Schultz DM, Smith HS, Cohen SP. Spinal cord stimulation for patients with failed back surgery syndrome: A systematic review. Pain Physician 2009; 12:379-397.

48. Patel VB, Manchikanti L, Singh V, Schultz DM, Hayek SM, Smith HS. Systematic review of intrathecal infusion systems for long-term management of chronic non-cancer pain. Pain Physician 2009; 12:345-360.

49. Rupert MP, Lee M, Manchikanti L, Datta S, Cohen SP. Evaluation of sacroiliac joint interventions: A systematic appraisal of the literature. Pain Physician 2009; 12:399-418.

50. Salaffi F, Stancati A, Silvestri CA, Ciapetti A, Grassi W. Minimal clinically important changes in chronic musculoskeletal pain intensity measured on a numerical rating scale. Eur J Pain 2004; 8:283-291.

51. Farrar JT, Young JP Jr, LaMoreaux L, Werth JL, Poole RM. Clinical importance of changes in chronic pain intensity measured on an 11-point numerical pain rating scale. Pain 2001; 94:149158.

52. Bombardier C. Outcome assessments in the evaluation of treatment of spinal disorders: Summary and general rec- ommendations. Spine 2000; 25:31003103.

53. Manchikanti L, Hirsch JA, Smith HS. Evidence-based medicine, systematic reviews, and guidelines in interventional pain management: Part 2: Randomized controlled trials. Pain Physician 2008; 11:713-775.

54. Manchikanti L, Benyamin RM, Helm S, Hirsch JA. Evidence-based medicine, systematic reviews, and guidelines in interventional pain management: Part 3: Systematic reviews and meta-analysis of randomized trials. Pain Physician 2009; 12:35-72.

55. Manchikanti L, Singh V, Smith HS, Hirsch JA. Evidence-based medicine, systematic reviews, and guidelines in interventional pain management: Part 4: Observational studies. Pain Physician 2009; 12:73-108.

56. Manchikanti L, Singh V, Falco FJE, Cash KA, Pampati V. Effectiveness of thoracic medial branch blocks in managing chronic pain: A preliminary report of a randomized, double-blind controlled trial: Clinical trial NCT00355706. Pain Physician 2008; 11:491-504.

57. Manchikanti L, Singh V, Falco FJ, Cash KA, Fellows B. Cervical medial branch blocks for chronic cervical facet joint pain: A randomized double-blind, controlled trial with one-year follow-up. Spine 2008; 33:1813-1820.

58. Manchikanti L, Singh V, Falco FJ, Cash KA, Pampati V. Lumbar facet joint nerve blocks in managing chronic facet joint pain: One-year follow-up of a randomized, double-blind controlled trial: Clinical Trial NCToo355914. Pain Physician 2008; 11:121-132.

59. Manchikanti L, Cash KA, McManus CD, Pampati V, Smith HS. Preliminary results of randomized, equivalence trial of fluoroscopic caudal epidural injections in managing chronic low back pain: Part 1 . Discogenic pain without disc herniation or radiculitis. Pain Physician 2008; 11:785-800.

6o. Manchikanti L, Singh V, Cash KA, Pampati V, Damron KS, Boswell MV. Preliminary results of randomized, equivalence trial of fluoroscopic caudal epidural injections in managing chronic low back pain: Part 2. Disc herniation and radiculitis. Pain Physician 2008; 11:801-815.

61. Manchikanti L, Singh V, Cash KA, Pampati V, Datta S. Preliminary results of randomized, equivalence trial of fluo- 
roscopic caudal epidural injections in managing chronic low back pain: Part 3. Post surgery syndrome. Pain Physician 2008; 11:817-831.

62. Manchikanti L, Cash KA, McManus CD, Pampati V, Abdi S. Preliminary results of randomized, equivalence trial of fluoroscopic caudal epidural injections in managing chronic low back pain: Part 4. Spinal stenosis. Pain Physician 2008; 11:833-848.

63. Manchikanti L, Boswell MV, Giordano J. Evidence-based interventional pain management: Principles, problems, potential, and applications. Pain Physician 2007; 10:329-356.

64. Manchikanti L. Evidence-based medicine, systematic reviews, and guidelines in interventional pain management: Part 1: Introduction and general considerations. Pain Physician 2008; 11:161-186.

65. Berg AO, Allan JD. Introducing the third U.S. Preventive Services Task Force. Am J Prev Med 2001; 20:S3-S4.

66. Guyatt G, Gutterman D, Baumann MH, Addrizzo-Harris D, Hylek EM, Phillips B, Raskob G, Lewis SZ, Schünemann $\mathrm{H}$. Grading strength of recommendations and quality of evidence in clinical guidelines. Report from an American College of Chest Physicians Task Force. Chest 2006; 129:174-181.

67. Singh V, Piryani C, Liao K, Nieschultz S. Percutaneous disc decompression using coblation (nucleoplasty) in the treatment of chronic discogenic pain. Pain Physician 2002; 5:250-259.

68. Sharps LS, Isaac Z. Percutaneous disc decompression using Nucleoplasty. Pain Physician 2002; 5:121-126.

69. Welch WC, Gerszten PC. Alternative strategies for lumbar discectomy: Intradiscal electrothermy and nucleoplasty. Neurosurg Focus 2002; 13:E7.

70. Singh V, Piryani C, Liao K. Role of percutaneous disc decompression using coblation in managing chronic discogenic low back pain: A prospective, observational study. Pain Physician 2004; 7:419-425.

71. Singh V, Piryani C, Liao K. Evaluation of percutaneous disc decompression using coblation in chronic back pain with or without leg pain. Pain Physician 2003; 6:273-280.

72. Marin FZ. CAM versus nucleoplasty. Acta Neurochir Suppl 2005; 92:111-114.

73. Gerszten PC, Welch WC, King JT. Quality of life assessment in patients undergoing nucleoplasty-based percutaneous discectomy. J Neurosurg Spine 2006; 4:36-42.

74. Alexandre A, Coro L, Azuelos A, Pellone M. Percutaneous nucleoplasty for discoradicular conflict. Acta Neurochir Suppl 2005; 92:83-86.

75. Bhagia SM, Slipman CW, Nirschl M, Isaac Z, El-Abd O, Sharps LS, Garvin C. Side effects and complications after percutaneous disc decompression using coblation technology. Am J Phys
Med Rehabil 2006; 85:6-13.

76. Cohen SP, Williams S, Kurihara C, Griffith S, Larkin TM. Nucleoplasty with or without intradiscal electrothermal therapy (IDET) as a treatment for lumbar herniated disc. J Spinal Disord Tech 2005; 18:S119-S124.

77. Mirzai H, Tekin I, Yaman O, Bursali A. The results of nucleoplasty in patients with lumbar herniated disc: A prospective clinical study of 52 consecutive patients. Spine J 2007; 7:88-92.

78. Reddy AS, Loh S, Cutts J, Rachlin J, Hirsch JA. New approach to the management of acute disc herniation. Pain Physician 2005; 8:385-390.

79. Wang JC, Kabo JM, Tsou PM, Halevi L, Shamie AN. The effect of uniform heating on the biomechanical properties of the intervertebral disc in a porcine model. Spine J 2005; 5:64-70.

80. Al-Zain F, Lemcke J, Killeen T, Meier U, Eisenschenk A. Minimally invasive spinal surgery using nucleoplasty: A 1year follow-up study. Acta Neurochir (Wien) 2008; 150:1257-1262.

81. Yakovlev A, Tamimi MA, Liang H, Eristavi M. Outcomes of percutaneous disc decompression utilizing nucleoplasty for the treatment of chronic discogenic pain. Pain Physician 2007; 10:319-327.

82. Smuck M, Benny B, Han A, Levin J. Epidural fibrosis following percutaneous disc decompression with coblation technology. Pain Physician 2007; 10:691-696. 